\title{
Effect of IPD Implementation and Communication between Contractor and Owner on the Success of a Building Project in Jakarta Barat
}

\author{
Riko Harjono", Henni Gusfa², Bambang Purwoko Kusuma Bintoro ${ }^{3}$ \\ ${ }^{1}$ Student of Construction Management Master's Program, Universitas Mercu Buana, Jakarta, Indonesia \\ ${ }^{2}$ Master of Communication Sciences Program, Universitas Mercu Buana, Jakarta, Indonesia \\ ${ }^{3}$ Master of Management Program, Universitas Bakrie, Jakarta, Indonesia
}

Corresponding Author: Riko Harjono

\begin{abstract}
The contractual working relationship between the contractor and the assignor in implementing a project is very complex. So that in achieving the success of the project, a project implementation system with integrated delivery and effective communication between organizations is needed. This study aims to analyze project success in terms of integrated project delivery and communication between contractors and task givers. The independent variables used in this study are integrated project delivery (x1) and communication (x2). The dependent variable used is project success (y). The samples in this study were 42 respondents. Data were collected by distributing questionnaires. The collected data were analyzed using structural equation modeling (SEM) with validity, reliability and hypothesis testing. The results showed that the implementation of integrated project delivery and communication had a positive and significant effect on the success of the project between the contractor and the assignor. Meanwhile, influential indicators are: innovative project delivery system (x1.20) and the coordination relationship between the project office and the head office (x2.15).
\end{abstract}

Keywords: Integrated project delivery, Komunikasi, Kontraktor, Owner, Keberhasilan Proyek

\section{INTRODUCTION}

The growth of the construction service industry in the private sector and the accelerated development program launched by the government has shown a fairly rapid increase in the value of the construction sector. The growth of building projects in West Jakarta has experienced an increasing growth.

One of the main causes of low productivity is related to the chosen project delivery method. The first factor is traditional methods such as design-bid-build dividing the parties involved in the design and construction stages. There is an increasing trend in more integrated project delivery (IPD) in the construction industry [1]. Delivery of a construction project involves several elements of the project which have the goal of making the

In every project implementation, there is communication of every stakeholder involved in the project to carry out their roles so that the project can be realized ${ }^{[2]}$. Today communication has become an essential element of every organization. In the construction industry, information must be accurately and timely communicated among project stakeholders to realize project objectives through managing information communication in coordination with project stakeholders. The facts that occur in projects often conflict in its implementation between the work relationship of the owner and the contractor because of bad communication relationships [3].

So that there is work complexity where there is a potential for conflict 
between the owner and the contractor in project implementation will greatly affect the quality of their relationship, thus affecting the success of the project ${ }^{[4]}$. The effect of this on dynamic communication can hinder the continuity of contractual work relationships, so that efforts are needed to make changes in communication management in achieving organizational goals and objectives.

Taking into account the background and problem identification as mentioned above, a problem formulation is made, as follows:

- Does the implementation of integrated project delivery between the contractor and assignor have an effect on project success?

- Does communication between contractor and assignor influence the project success?

- What factors in the communication between contractor and assignor influence project success?

The research objective is to analyze the factors that influence the communication between the contractor and the assignor in the project's success.

\section{LITERATURE REVIEW}

A project is a temporary effort made to create a unique product, service or result [5]. To achieve project objectives effectively, efficiently and on target requires appropriate project delivery methods and contract management.

\subsection{Integrated Project Delivery}

According to the Design-Build Institute of America (AIA, CC) in its official release: A project delivery method that integrates people, system, business structures and practices into a process that collaboratively harnesses the talents and insights of all participant to reduce waste and optimize efficiency through all phases of design, fabrication and construction ${ }^{[6]}$.

The minimum integrated project delivery method consists of several factors, as follows:
- Ongoing involvement of owners and planners and contractors from design inception to completion of project work.

- Common business interests are aligned through risk / reward, including financial gain at risk depending on project results.

- Joint project control by owners and planners and contractors.

- Multi-party agreements or interrelated agreements.

- Limited liability between owner and planner and contractor.

In integrated project implementation, the project cycle from conceptualization through implementation and closure differs significantly from that of a non-integrated project. Integrated Project Delivery provides positive value propositions for the project's three main stakeholder groups, as follows:

- Owner: The initial and open sharing of project knowledge simplifies project communication and allows owners to balance project options effectively to meet their corporate business goals.

- Constructors: to contribute their expertise in construction engineering early in the design process which results in improved project quality and financial performance during the construction phase.

- Designers: to benefit from the initial contribution of the constructor's expertise during the design phase, such as accurate budget estimates to inform design decisions and the completion of pre-construction design-related problems that result in improved project quality and financial performance.

\subsection{Project Management Communication}

Communication becomes a medium for delivering instructions on how the project should be understood together, both from when the project starts, when the project has little time and the solution to the project delays and when the project schedule should end and what the consequences of the delay are. 
Riko Harjono et.al. Effect of IPD implementation and communication between contractor and owner on the success of a building project in Jakarta Barat.

In the implementation of communication management in projects generally includes the processes necessary to ensure that information needs and stakeholders are met through the development and implementation of activities designed to achieve the required exchange of information. Communication management planning, namely: communication planning, communication management and communication monitoring.

\section{MATERIALS \& METHODS}

This research is quantitative with a descriptive approach, using interview techniques and questionnaires. The respondents' interviews consisted of experts and experts in construction management and communication.

Meanwhile, the respondents for the questionnaire came from parties involved in construction project activities such as project owners, contractors, consultants and professionals. In this study there are two variables, namely the dependent variable $(\mathrm{Y})$ and the independent variable (X1), table 1 and (X2), table 2. The dependent variables are time, cost, quality and safety. While the independent variables are integrated project delivery and communication,

Table 1. The operational definition of the integrated project delivery (X1)

\begin{tabular}{|c|c|c|}
\hline Subvariabel/Dimensions & Indicator & References \\
\hline \multirow[t]{5}{*}{ Principles of Contract } & Effectiveness of project teamwork in achieving target (X1.1) & 11 \\
\hline & Collaboration in decision making (X1.2) & 13 \\
\hline & Each stakeholder has a role (X1.3) & 12 \\
\hline & Early involvement (X1.4) & 12 \\
\hline & Awareness of riks and rewards (X1.5) & 14 \\
\hline \multirow[t]{5}{*}{ Tradition } & Maintain professional code of ethics (X1.6) & 13 \\
\hline & Open and effective communication (X1.7) & 13 \\
\hline & Mutual trust (X1.8) & 14 \\
\hline & Commitment between stakeholder (X1.9) & 15 \\
\hline & Solid team $(\mathrm{X} 1.10)$ & 15 \\
\hline \multirow[t]{5}{*}{ Communication } & Carry out careful monitoring of project progress (X1.11) & 19 \\
\hline & Project coordinator manages team with good communication management (X1.12) & 19 \\
\hline & The project team is able to overcome obstacles/challenge with good problem solving (X13) & 15,19 \\
\hline & Able to negotiate well on problems with various parties (X1.14) & 15,19 \\
\hline & Digital use, virtual design (BIM, ICT, dll) (X1.15) & 1,12 \\
\hline \multirow[t]{5}{*}{ Benefit } & Increase opportunities and confidence of the construction market (X1.16) & $1,14,16$ \\
\hline & Reducing waste and optimal efficiency (X1.17) & 1,14 \\
\hline & Mereduksi waste dan efisiensi yang optimal (X1.18) & 14 \\
\hline & Good interdisciplinary coordinationk (X1.19) & 14 \\
\hline & Innovative project delivery systemf $(\mathrm{X} 1.20)$ & 16 \\
\hline
\end{tabular}

Table 1. The operational definition of the communication variablei (X2)

\begin{tabular}{|l|l|l|}
\hline Subvariabel/Dimensions & Indikator & References \\
\hline Communication devices & Coodination meetings (X2.1) & 7 \\
\cline { 2 - 3 } & Unit mock-up (X2.2) & 7 \\
\cline { 2 - 3 } & Use of ICT (email, whatsapp, social media) (X2.3) & 9 \\
\cline { 2 - 3 } & Meeting facilities available (X2.4) & 9 \\
\hline \multirow{5}{*}{$\begin{array}{l}\text { Kemunikasi Efektif } \\
\text { Berkomunikasi }\end{array}$} & Solid project team (X2.5) & 7 \\
\cline { 2 - 3 } & Collaborative culture (X2.6) & 7 \\
\cline { 2 - 3 } & Problem solving (X2.7) & 3,20 \\
\hline \multirow{5}{*}{ Laporan Kinerja } & Clarity of message content (X2.8) & 3,18 \\
\cline { 2 - 3 } & Two-way communication (X2.9) & 9 \\
\cline { 2 - 3 } & Information distribution system with coordination meetings (X2.10) & 9 \\
\cline { 2 - 3 } & Clarity of monthly reports on project progress (X2.11) & 9 \\
\hline Hubungan Koordinasi & Clarity of work monthly reports (X2.12) & 9 \\
\cline { 2 - 3 } & Claruty of monthly reports on jon changes (X2.13) & 9 \\
\cline { 2 - 3 } & The accuracy of distribution of printed documents (X2.14) & 9 \\
\cline { 2 - 3 } & Project office coordination relation ship with head office (X2.15) \\
\cline { 2 - 3 } & Implementattion coordination relationship within the internal work team (X2.16) & 9,18 \\
\cline { 2 - 3 } & Coordination relationship between contractor and owner (X2.17) \\
\cline { 2 - 3 } & Able to communicate and understand language usage (X2.18) \\
\hline
\end{tabular}

Data collection was carried out through a method using questions, where the researcher distributed questionnaires and interviews to respondents through several 
Riko Harjono et.al. Effect of IPD implementation and communication between contractor and owner on the success of a building project in Jakarta Barat.

stages as follows: (1) The first stage clarifies the independent variables for experts. (2) The second stage is to collect data from respondents. (3) The third stage of data analysis. The statistical analysis method used is PLS-SEM (partial least squares) by testing the validity and reliability of the questionnaire results. This research instrument with a questionnaire form related to the research data needed and then distributed to respondents for their responses. The measurement technique uses a Likert scale, which consists of a scale of 1-4 with information that shows strongly disagree to strongly agree in table 2 .

Table 2. Measurement scale

\begin{tabular}{|l|l|l|}
\hline Scale & Appraisal & Notes \\
\hline 1 & $25 \%$ & Totally disagree \\
\hline 2 & $50 \%$ & Disagree \\
\hline 3 & $75 \%$ & Agree \\
\hline 4 & $100 \%$ & Strongly agree \\
\hline
\end{tabular}

\section{RESULT \& DISCUSSION}

The questionnaire survey was carried out by distributing 50 questionnaires and 42 questionnaires were successfully filled in. the result of the questionnaires collection as input were processed by partial least square analysis using the SmartPLS method. From testing the measuring instrument with model analysis that has been carried out 5 times and the outer mpdel value is obtained which indicates that the indicator meet the validity and reliability requirement which can be seen in figure 1 and table 3.

\begin{tabular}{|c|c|c|c|}
\hline & $\mathrm{X} 1$ & $\mathrm{X} 2$ & $\mathrm{Y}$ \\
\hline X1.6 & 0,668 & & \\
\hline X1.8 & 0,617 & & \\
\hline X1.9 & 0,794 & & \\
\hline $\mathrm{X} 1.10$ & 0,720 & & \\
\hline $\mathrm{X} 1.12$ & 0,710 & & \\
\hline $\mathrm{X} 1.14$ & 0,691 & & \\
\hline $\mathrm{X} 1.17$ & 0,796 & & \\
\hline $\mathrm{X} 1.18$ & 0,816 & & \\
\hline $\mathrm{X} 1.19$ & 0,717 & & \\
\hline $\mathrm{X} 1.20$ & 0,876 & & \\
\hline $\mathrm{X} 2.1$ & & 0,778 & \\
\hline $\mathrm{X} 2.5$ & & 0,773 & \\
\hline X2.9 & & 0,742 & \\
\hline $\mathrm{X} 2.11$ & & 0,803 & \\
\hline $\mathrm{X} 2.12$ & & 0,806 & \\
\hline $\mathrm{X} 2.14$ & & 0,711 & \\
\hline X2.15 & & 0,855 & \\
\hline $\mathrm{X} 2.16$ & & 0,796 & \\
\hline $\mathrm{X} 2.17$ & & 0,842 & \\
\hline Y1 & & & 0,799 \\
\hline $\mathrm{Y} 2$ & & & $\mathbf{0 , 8 2 3}$ \\
\hline Y3 & & & $\mathbf{0 , 8 8 3}$ \\
\hline Y4 & & & $\mathbf{0 , 8 3 2}$ \\
\hline
\end{tabular}

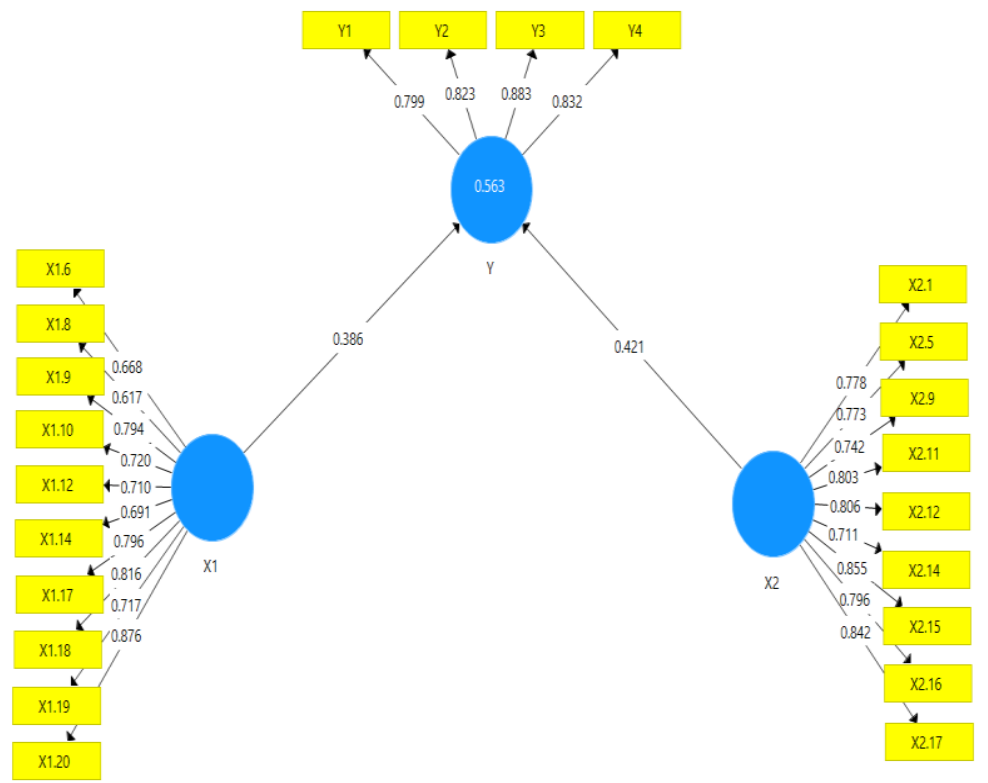

Figure 1 model 5 already analysis

\subsection{Outer Loading Measurement}

Then proceed with test construct reliability, which measures the reliability of latent variable constructs. The value that is considered reliable must be above 0,70 . 
Riko Harjono et.al. Effect of IPD implementation and communication between contractor and owner on the success of a building project in Jakarta Barat.

Construct reliability is the same as Cronbach's alpha which is shown in table 4.

Table 4. Test construct reliability

\begin{tabular}{|l|l|l|l|l|}
\hline & $\begin{array}{l}\text { Cronbach's } \\
\text { Alpha }\end{array}$ & rho_A & $\begin{array}{l}\text { Composite } \\
\text { Reliability }\end{array}$ & AVE \\
\hline X1 & $\mathbf{0 , 9 2 3}$ & $\mathbf{0 , 9 4 1}$ & $\mathbf{0 , 9 3 5}$ & $\mathbf{0 , 5 6 8}$ \\
\hline X2 & $\mathbf{0 , 9 4 3}$ & $\mathbf{0 , 9 4 8}$ & $\mathbf{0 , 9 5 1}$ & $\mathbf{0 , 6 1 6}$ \\
\hline Y & $\mathbf{0 , 8 5 6}$ & $\mathbf{0 , 8 6 8}$ & $\mathbf{0 , 9 0 2}$ & $\mathbf{0 , 6 9 7}$ \\
\hline
\end{tabular}

Table 5. Test discriminat validity

\begin{tabular}{|l|l|l|l|}
\hline & $X 1$ & $X$ & $Y$ \\
\hline$X 1$ & $\mathbf{0 , 7 4 4}$ & & \\
\hline$X 2$ & $\mathbf{0 , 7 2 8}$ & $\mathbf{0 , 7 9 1}$ & \\
\hline$Y$ & $\mathbf{0 , 6 9 3}$ & $\mathbf{0 , 7 0 2}$ & $\mathbf{0 , 8 3 5}$ \\
\hline
\end{tabular}

Then proceed with the discriminate validity test, which is a construct capable of explaining the measured phenomenon and is said to be valid by comparing the AVE root value with the correlation value between latent variable, which is shown in table 5.

\subsection{Inner Loading Measurement}

The result of the inner model obtained, as follows:

- $\mathrm{R}^{2}, 0,33<\mathbf{0 , 5 6 3}<0,67$ (that all independent variables affect $\mathrm{Y}$ moderately).

- $\mathrm{Q}^{2}, 0<\mathbf{0 , 5 6 3}$ (that the predictions made by the model are considered relevant).

- $\mathrm{F}^{2}(\mathrm{X} 1),=\mathbf{0 , 1 6 0}$ (has a substantive effect).

- $\mathrm{F}^{2}(\mathrm{X} 2),=\mathbf{0 , 1 9 1}$ (has a substantive effect).

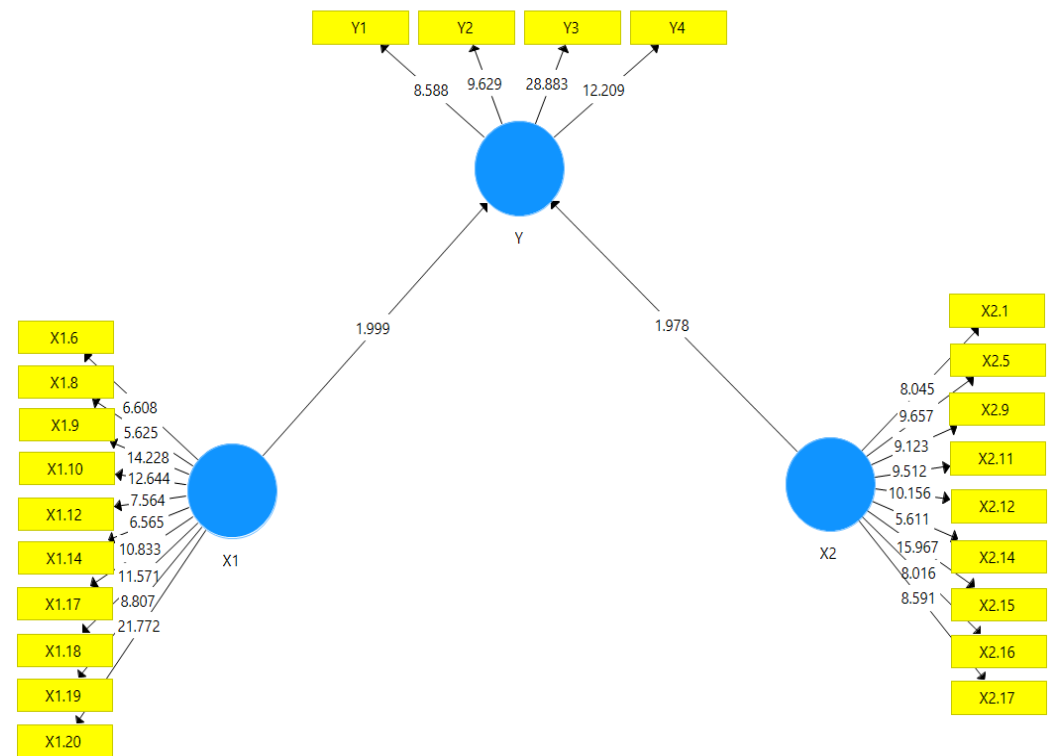

Figure 2 Bootstrapping

\subsection{Hypothesis test}

The result of hypothesis testing show that the variables $\mathrm{X}$ and $\mathrm{X} 2$ have an influence on project success which can be seen in figure 2 and table 6.

Table 6. TestT-Statistic dan P-Values

Table 6. TestT-Statistic dan P-Values
\begin{tabular}{|l|l|l|}
\hline & T-Statistic & P-Values \\
\hline X1 $-----\rightarrow Y$ & $\mathbf{1 , 9 9 9}$ & $\mathbf{0 , 0 4 6}$ \\
\hline X2 $----\rightarrow Y$ & $\mathbf{1 , 9 7 8}$ & $\mathbf{0 , 0 4 8}$ \\
\hline
\end{tabular}

\subsection{DISCUSSION}

1. Does the implementation of integrated project delivery between the contractor and the assignor have an effect on the success of the project, the results are acceptable because the T-Statistic is 1.999 and P-values $0.046<0.05$. Where the indicators have a very high influence, namely: an innovative project delivery system.

2. Does the communication between the contractor and the assignor affect the success of the project, the results are acceptable because the T-Statistic is 1.978 and a P-value of $0.048<0.05$. Where the indicators have a very high influence, namely: the coordination relationship between the project office and the head office. 
3. What factors in the implementation of an integrated project delivery and communication between the contractor and the assignor have an effect on project success, as follows:

- Tradition: maintaining professional code of ethics, mutual trust, commitment between stakeholders, solid team formation.

- Communication: the project coordinator manages the team with good communication management, is able to negotiate well on problems with various parties.

- Benefits: predictable costs and scheduling, reduce waste and optimal efficiency, good interdisciplinary coordination, innovative project delivery systems.

- Communication devices: coordination meetings

- Effective communication: solid project team

- Communication skills: two-way communication, clear monthly reports on project progress.

- Performance reports: clarity of work monthly reports, accuracy of distribution of printed documents.

- Coordination relationship: the coordination relationship between the project office and the head office, the coordination relationship between the implementation of the internal work team, the coordination relationship between the contractor and the owner.

\section{CONCLUSION}

The result shows that project success can influence the project implementation system using integrated project delivery and communication management.

Influenced by the project implementation system using integrated project delivery and good management communication management.

The measurement of the IPD variable shows that the contract dimension does not only affect the dimensions of tradition, communication and benefits. Of course, this is influenced by existing regulations in Indonesia which may not necessarily accommodate an integrated implementation system. The measurement of the communication variable shows that all the dimensions are represented by indicators. Where the indicators are very influential, namely: the coordination relationship between the project office and the head office shows that organizational communication needs good communication management by the communicators who are predominantly male as much as $88.1 \%$. Contract-based behavior certainly requires a rational attitude and an orientation to work relations.

\section{REFERENCES}

1. Gomez S, Naderpajouh $\mathrm{N}$, Ballard G, Hastak M, Weidner TJ, Barriaga P. Implications of the Integrated Project Delivery Research in Practice. Proceeding Constr Res Congr 2018. Published online 2018;148-157. doi:10.1213/01.ANE.0000149897.87025.A8

2. Dainty, A, Moore D, M. M. Communication in Construction Design. 2 Park Square, Milton Park, Abingdon, Oxon OX 14 4RN: First published 2006.

3. Ishaq, I. M., Omar, R., \& Mohammed, M. Challenges of Communication between the Client and Contractor during Construction Projects: The Nigerian Perspective, International Journal of Engineering and Modern Technology. 2018; 4(2), 20-29.

4. Lu, W., \& Wang, J. The influence of conflict management styles on relationship quality: The moderating effect of the level of task conflict. International Journal of Project Management, 2017; 35(8), 14831494.

5. Project management Institute, Inc. Pedoman Kerangka Manajemen Proyek, PMBOK $^{\circledR}$ Guide, edisi enam. PMI Indonesia Chapter. 2017.

6. AIA, American Institute of Architects. 2007. "Integrated Project Delivery: A Guide." Accessed July 25, 2018.

7. Yap, JBH., Abdul-Rahman, H., \& Wang, C., Preventive Mitigation of Overruns with Project Communication Management and 
Riko Harjono et.al. Effect of IPD implementation and communication between contractor and owner on the success of a building project in Jakarta Barat.

Continuous Learning: PLS-SEM Approach. ASCE. 2018.

8. Ade, A., Saputra, I., Margaret, R., Yanti, K., 2017. Pengaruh Komunikasi TerhadapKeberhasilan Proyek Pada Hubungan Kerja Antara Kontraktor dan Subkontraktor, Jurnal Sains Terapan Vol. 3 No. 2 Oktober 2017; 3(2).

9. Ripkianto, R., \& Yanti, K., Pengaruh Komunikasi TerhadapKeberhasilan Proyek Pada Hubungan Kerja Antara Kontraktor dan Subkontraktor, Konferensi Nasional Teknik Sipil 7 (KoNTekS 7). 2013.

10. AIA, American Institute of Architects. 2007. "Integrated Project Delivery: A Guide." Accessed July 25, 2018. Manata, B., Miller, V., Mollaoglu, S., Measuring Key Communication Behaviors in Integrated Project Delivery Teams. ASCE. 2018. 34(4), 1-7.

11. Pishdad-bozorgi, P., Srivastava, D., Assessment of Integraed Project Delivery (IPD) Risk and Reward Sharing Strategies from the Standpoint of Collaboration: a Game Theory Approach. ASCE. 2018.

12. Hanna, AS., \& Asce, F. Benchmark Performance Metrics for Integrated Project Delivery. ASCE. 2016; 1-9.

13. Zhang, L., Qian Q,. Exploring the factor for Collaboration Relationships in IPD project. 2016.

14. Choi, J,. Yun, S., Leite, F,. Mulva, SP., Team Integration and owner Satisfaction: Comparing Integrated Project Delivery. ASCE. 2018
15. Garcia, A.J., Manata, B., Mollaoglu, S., Miller, V., Key Information Sharing Behaviors for Improved Performance in IPD Project. ASCE. 2016.

16. Rahim, S. A., Nawi, MNM,. Nifa, FAA,. Integrated Project Delivery (IPD) a Collaboration Approach to Improve the Contruction Industry. Advanced Science Letter. 2016.

17. Jayasena, HS., Senevirathna, NS., Adaptability Integrated Project Delivery in Contruction Industry. Construction Conference, Global Challenges in Constuction Industry, 2012.

18. Gamil, Y., Rahman, IA., Identification of Causes and Effects of Poor Communication in Construction Industry: a Theoretical Review, Emerging Science Journal, 2017.

19. Manata, B., Miller, V., Mollaoglu, S., Garcia, A.J., Measuring Key Communication Behaviors in Integrated Project Delivery Teams. ASCE. 2018.

20. Wu, G., Liu, C., Zhao, X., Zuo, J., Investigating the Relationship Between Communication-Conflict Iteration and Project Success Among Construction Project Teams. Science Direct. 2017.

How to cite this article: Harjono R, Gusfa H, Bintoro BPK. Effect of IPD implementation and communication between contractor and owner on the success of a building project in Jakarta Barat. International Journal of Research and Review. 2021; 8(3): 51-57. 